\title{
ANALISIS KEPERCAYAAN GENERASI MILENIAL TERHADAP LEMBAGA KEUANGAN SYARIAH
}

\author{
Emilia Septiani ${ }^{1}$, Mulyadi $^{2}$, Sarifudin $^{3}$ \\ ${ }^{1}$ Fakultas Ekonomi dan Bisnis Universitas Mataram, Mataram, emiliaseptiani@unram.ac.id \\ ${ }^{2}$ Fakultas Ekonomi dan Bisnis Universitas Mataram, Mataram, mulyadiunram@gmail.com \\ ${ }^{3}$ Fakultas Ekonomi dan Bisnis Universitas Mataram, Mataram, sarifudinserip.fe@unram.ac.id
}

\begin{tabular}{ll|lll}
\hline Article history & \multicolumn{3}{l}{} \\
\hline Dikirim tanggal & $: 03 / 05 / 2021$ & Diterima tanggal & $:$ & $13 / 08 / 2021$ \\
Revisi pertama tanggal & $: 13 / 08 / 2021$ & Tersedia online tanggal & $:$ & $08 / 09 / 2021$ \\
\hline
\end{tabular}

\begin{abstract}
ABSTRAK
Tujuan dari penelitian ini adalah untuk menganalisis kepercayaan generasi milenial terhadap lembaga keuangan syariah. Kepercayaan generasi milenial mengacu pada prinsip Good Corporate Governance (GCG) yang terdiri dari keterbukaan, akuntabilitas, pertanggungjawaban, independensi, kewajaran dan shariah compliance. Metode pengumpulan data yang digunakan adalah metode sampel survei. Jumlah sampel dalam penelitian ini sebesar 150 sampel. Teknik pengambilan sampel yang digunakan dalam penelitian ini adalah accidental sampling. Alat analisis yang digunakan adalah statistik deskriptif.

Hasil penelitian ini menunjukkan bahwa kepercayaan generasi milenial terhadap lembaga keuangan syariah tinggi. Hal ini membuktikan bahwa para generasi milenial yang ada di Provinsi Nusa Tenggara Barat pada dasarnya sudah memiliki kepercayaan yang baik terhadap operasionalisasi lembaga keuangan syariah.
\end{abstract}

Kata Kunci: Kepercayaan, generasi milenial, lembaga keuangan syariah.

\begin{abstract}
The purpose of this study is to analyze the trust of the millennial generation in Islamic financial institutions. The trust of the millennial generation refers to the principles of Good Corporate Governance (GCG) which consists of transparancy, accountability, responsibility, independence, fairness and sharia compliance. The data collection method used was the sample survey. The number of samples in this study was 150 samples. The sampling technique used in this study was accidental sampling. The analytical tool used is descriptive statistics.

The results of this study indicate that the millennial generation's trust in Islamic financial institutions is high. This proves that the millennial generation in West Nusa Tenggara Province basically already has good trust in the operation of Islamic financial institutions.
\end{abstract}

Keywords: Trust, millenial genration, Islamic financial institutions. 


\section{PENDAHULUAN}

\section{Latar Belakang}

Prinsip keuangan syariah pada dasarnya telah dirintis di Indonesia sejak tahun 1911. Hal ini ditandai dengan beridirinya Serikat Dagang Islam yang dipelopori oleh para pengusaha dan tokoh-tokoh Islam pada era tersebut. Sayangnya beberapa tahun setelahnya, perkembangan ekonomi Islam di Indonesia seolah kehilangan momentumnya. Geliat ekonomi Islam mulai diraskan kembali pada tahun 1992 (legitimasi menurut UU No.7 Tentang Perbankan) dengan didirikannya Bank Muamalat Indonesia (BMI). Berdirinya BMI seolah membawa angin segar bagi industri keuangan syariah di Indonesia karena mulai menunjukkan sebuah perkembangan yang sangat positif. Setelah didirikannya BMI, berikutnya didirikan Asuransi Syariah Takaful pada tahun 1994 yang diikuti dengan berdirinya 78 Bank Perkreditan Rakyat (BPR) syariah (Agustianto, 2011).

Seiring berjalannya waktu, aset keuangan industri syariah terus menunjukkan peningkatan yang cukup baik. Berdasarkan hasil Laporan Perkembangan Keuangan Syariah Indonesi (LKSI) Tahun 2018, aset keuangan syariah Indonesia telah menembus angka Rp. 1,2 triliun. Berikut rincian mengenai total aset keuangan syariah Indonesia per tahun 2018.

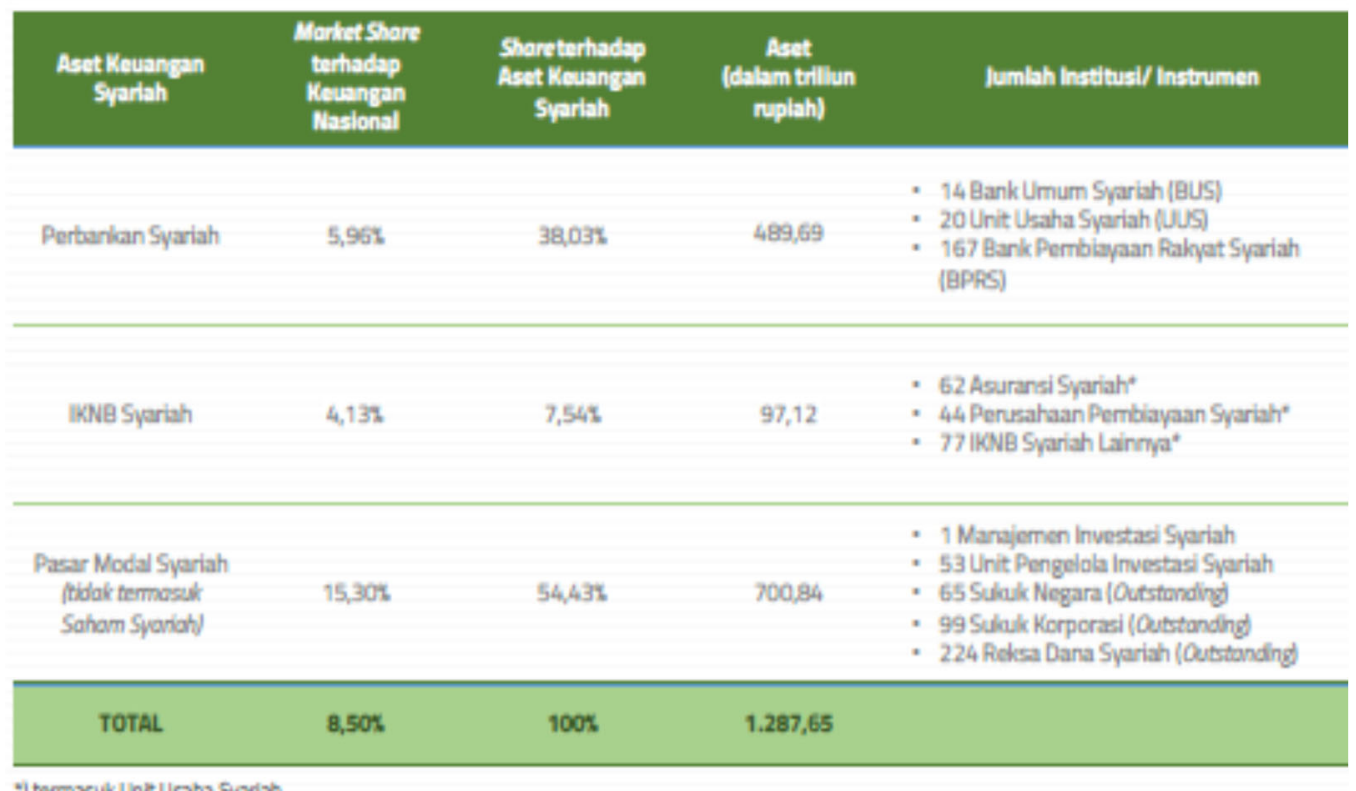

Gambar 1. Total Aset Keuangan Syariah Indonesia Tahun 2018

Memang jika melihat pertumbuhan secara nasional, pertumbuhan aset perbankan syariah selalu kalah dengan pertumbuhan aset perbankan konvensional. Aset keuangan syariah hanya bisa tumbuh $\pm 1 \%$ per tahun, sedangan lembaga keuangan konvensional bisa mencapai $7 \%$ per tahun.

Perkembangan aset keuangan syariah juga terjadi di Provinsi Nusa Tenggara Barat (NTB). Perkembangan aset syariah, terutama perbankan syariah, mengalami pertumbuhan mencapai 30,70\% per Januari - Oktober 2019 dengan nilai aset menembus Rp. 15,2 triliun. Bahkan menurut Kepala Otoritas Jasa Keuangan (OJK) Provinsi NTB, Farid Faletehan, pertumbuhan industri keuangan syariah di NTB jauh melampaui pertumbuhan nasional. Hal ini mengindikasikan pada dasarnya sudah cukup banyak 
masyarakat Nusa Tenggara Barat yang menggunakan jasa keuangan syariah. Apalagi Pulau Lombok yang ada di NTB merupakan salah satu destinasi wisata halal yang mampu

Meskipun demikian, masih banyak masyarakat yang potensial untuk menjadi nasbah lembaga keuangan syariah. Salah satunya adalah generasi milenial. Generasi milenial merupakan generasi dengan tahun kelahiran antara tahun 1980 - 2000. Melihat rentang tahun kelahiran tersebut, usia generasi milenial merupakan usia produktif 20 tahun hingga 40 tahun. Hal ini didukung pula dengan data dari Badan Pusat Statistik Nusa Tenggara Barat yang menunjukkan bahwa jumlah penduduk generasi milenial di NTB mencapai $40 \%$ lebih dari total penduduk NTB yang sebanyak 4.955.578 jiwa per tahun 2017. Usia produktif tersebut merupakan pasar potensial dari segi karakteristik demografi bagi industri keuangan syariah.

Untuk dapat menarik minat generasi milenial ini, lembaga keuangan syariah harus mampu membentuk kepercayaan calon konsumen potensial. Kepercayaan ini dapat dibentuk salah satunya dengan cara menunjukkan bahwa lembaga keaungan syariah secara bersungguh-sungguh menerapkan shariah governance (Wardayanti, 2011; Junusi 2012). Implementasi dari shariah governance ini hanrus secara nyata terlihat agar mampu membentuk kepercayaan yang nantinya akan berujung pada keinginan (niat) untuk menggunakan jasa lembaga keuangan syariah, terutama produk investasi syariah (Billah, 2019; Larasati, 2019; dan Ningtyas, 2019). Dari fenomena tersebut, hasil penelitian terdahulu, dan melihat potensi pasar yang ada di NTB maka dirasa perlu dilakukannya penelitian mengenai kepercayaan para generasai milenial terhadap lembaga keuangan syariah

\section{Identifikasi Permasalahan}

Lebih dari $40 \%$ penduduk NTB merupakan generasi milenial. Usia produktif tersebut merupakan pasar potensial jika dilihat dari segi karakteristik demograsi bagi industri keuangan syariah. Untuk dapat menarik minat generasi milenial ini, lembaga keuangan syariah harus mampu membentuk kepercayaan calon konsumen potensial.

\section{Tujuan Penelitian}

Berdasarkan uraian pada latar belakang dan identifikasi masalah, maka tujuan dari dilakukannya penelitian ini adalah untuk menganalisi kepercayaan generasi milenial terhadap lembaga keuangan syariah.

\section{KAJIAN PUSTAKA}

\section{Industri Keuangan Syariah}

Industri keuangan syariah saat sejauh ini memilki prospek yang baik untuk dapat terus berkembang, bahkan Industri Keuangan Non-Bank (IKNB) yang berbasis syariah pun sudah menjadi salah satu pilar kekuatan di dalam industri keuangan syariah. Untuk lembaga keuangan bank, produk invetasi yang ditawarkan kepada masyarakat cukup beragam seperti tabungan, deposito, dan pembiayaan syariah. Untuk IKNB sendiri ada beberapa produk investasi yang ditawarkan, yaitu asuransi, dana pensiun, pembiayaan, dan jasa keuangan lainnya (www.ojk.go.id, 2017).

Menurut Dewan Syariah Nasional (DSN), Lembaga Keuangan Syariah (LKS) merupakan lembaga keuangan yang mengeluarkan produk keuangan syariah dan mendapatkan izin operasional sebagai lembaga keuangan syariah (DSN-MUI, 2003). Unsur kesesuaian sebuah LKS dengan syariah Islam secara tersentralisasi diatur oleh DSN dan telah diwujudkan dalam berbagai fatwa yang dikeluarkan oleh lembaga 
tersebut. Adapun untuk legalitas operasi sebagai lembaga keuangan diatur oleh berbagai instansi yang memiliki wewenang untuk mengeluarkan izin operasi.

Fatwa-fatwa DSN biasanya bersifat umum untuk semua LKS. Adapun fatwa yang dikeluarkan telah mengacu pada hukum-hukum muamalah yang dirumuskan oleh para ulama. Beberapa prinsip dalam hukum muamalah yang dianut oleh LKS adalah:

a. Pada dasaranya segala bentuk muamalah adalah mubah, kecuali yang ditentukan oleh Al-Qur'an dan sunnah rasul (prinsip mubah).

b. Muamalah dilakukan atas dasar sukarela tanpa mengandung unsur-unsur paksaan (prinsip sukarela).

c. Muamalah dilakukan atas dasar pertimbangan mendatangkan manfaat dan menghindarkan mudarat dalam hidup masyarakat (prinsip mendatangkan manfaat dan menghindarkan mudarat).

\section{Shariah Governance}

Istilah dari shariah governance dalam penelitian ini dikembangkan berdasarkan prinsip Good Corporete Governance (GCG) dan shariah complience. Prinsip GCG ini pada dasarnya mengatur mengenai hubungan institusional untuk memberikan arahan dan pengendalian bagi perusahaan (Wardayati, 2011). Merujuk pada Peraturan Bank Indonesia Nomor 11/33/PBI/2009 prinsip GCG lembaga keuangan syariah terdiri dari keterbukaan (transparancy), akuntabilitas (accountability), pertanggungjawaban (responsibility), independensi (independency), dan kewajaran (fairness).

Dalam ajaran Islam, kelima prinsip-prinsip pokok GCG di atas sesuai dengan norma dan nilai islami dalam aktivitas dan kehidupan seorang Muslim. Islam sangat intens mengajarkan diterapkannya prinsip 'adalah (keadilan), tawazun (keseimbangan), mas'ūliyah (akuntabilitas), akhlāq (moral), șiddīq (kejujuran), amānah (pemenuhan kepercayaan), fațanah (kecerdasan), tabligh (transparansi, keterbukaan), hurriyyah (independensi dan kebebasan yang bertanggung jawab), ihsān (profesional), wasatan (kewajaran), ghīrah (militansi syariah), idārah (pengelolaan), khiläfah (kepemimpinan), 'aqīdah (keimanan), ijābiyyah (berfikir positif), raqabah (pengawasan), qirā'ah dan ilāh (organisasi yang terus belajar dan selalu melakukan perbaikan) (Wardayati, 2011).

Dengan telah diimplementasikannya shariah governance pada lembaga keuangan syariah, diharapkan kedepannya mampu meningkatkan reputasi lembaga keuangan syariah di mata masyarakat terutama para generasi milenial. Generasi milenial memiliki kecenderungan untuk ingin tahu segala hal sehingga implementasi dari shariah governance ini hanrus secara nyata terlihat agar mampu membentuk kepercayaan yang nantinya akan berujung pada keinginan (niat) untuk menggunakan jasa lembaga keuangan syariah, terutama produk investasi syariah (Billah, 2019; Larasati, 2019; dan Ningtyas, 2019).

\section{Perilaku Generasi Milenial}

Menurut Manheim (sebagaimana dikutip dalam Yanuar, 2016)) generasi adalah suatu konstruksi sosial dimana didalamnya terdapat sekelompok orang yang memiliki kesamaan umur dan pengalaman historis yang sama. Lebih lanjut Manheim (1952) menjelaskan bahwa individu yang menjadi bagian dari satu generasi, adalah mereka yang memiliki kesamaan tahun lahir dalam rentang waktu 20 tahun dan berada dalam dimensi sosial dan dimensi sejarah yang sama. Dalam beberapa tahun terakhir definisi generasi telah berkembang, salah satunya adalah definisi menurut Kupperschmidt's (sebagaimana dikutip dalam Yanuar, 2016) yang mengatakan bahwa generasi adalah sekelompok individu yang mengidentifikasi kelompoknya berdasarkan kesamaan tahun kelahiran, 
umur, lokasi, dan kejadian-kejadian dalam kehidupan kelompok individu tersebut yang memiliki pengaruh signifikan dalam fase pertumbuhan mereka.

Menurut Howe \& Strauss (2000), ada tiga atribut yang lebih jelas mengidentifikasi generasi dibanding dengan tahun kelahiran, atribut tersebut antara lain:

1. Percieved membership: persepsi individu terhadap sebuah kelompok dimana mereka tergabung didalamnya, khususya pada masa-masa remaja sampai dengan masa dewasa muda.

2. Common belief and behaviors: sikap terhadap keluarga, karir, kehidupan personal, politik, agama dan pilihan-pilihan yang diambil terkait dengan pekerjaan, pernikahan, anak, kesehatan, kejahatan.

3. Common location in history: perubahan pandangan politik, kejadian yang bersejarah, contohnya seperti: perang, bencana alam, yang terjadi pada masa - masa remaja sampai dengan dewasa muda.

Dalam teori generasi (Generation Theory) yang dikemukakan Graeme Codrington \& Sue Grant-Marshall, Penguin, (2004) (sebagaimana dikutip oleh Simbolon, 2017) dibedakan 5 generasi manusia berdasarkan tahun kelahirannya, yaitu: (1) Generasi Baby Boomer, lahir 1946-1964; (2) Generasi X, lahir 1965-1980; (3) Generasi Y, lahir 1981-1994, sering disebut generasi millennial; (4) Generasi Z, lahir 1995-2010 (disebut juga iGeneration, GenerasiNet, Generasi Internet). Dan (5) Generasi Alpha, lahir 20112025. Kelima generasi tersebut memiliki perbedaan pertumbuh kembangan kepribadian.

Menurut publikasi yang diterbitkan Pricewaterhouse Coopers di tahun 2011, seseorang dikategorikan sebagai generasi milenial apabila ia lahir di antara periode 1980 sampai 2000. Sementara Howe dan Strauss (2003) menyebutkan bahwa generasi milenial adalah orang-orang yang lahir di antara tahun 1981 sampai tahun 2000. Senada dengan Howe dan Strauss (1991), Cooper (2012) juga sependapat melalui publikasi dari National Chamber Foundation (NCF), sebuah yayasan afiliasi dari U.S.Chamber of Commerce, bahwa generasi milenial merupakan orang-orang yang lahir antara tahun 1981-2000. Banyaknya variasi rentang periode membuat peneliti memilih untuk menggunakan rentang periode yang paling besar yakni antara tahun 1980 hingga 2000.

Millennial adalah sebuah gaya hidup. Millennial, demikian sebutan untuk generasi anak muda yang lahir dalam rentang tahun 1980-an hingga 2000. Saat ini sepertiga penduduk Indonesia atau 85 juta orang berusia produktif 15 tahun-34 tahun (data BPS). Usia seseorang dapat mempengaruhi sudut pandangnya akan suatu hal. Generasi ini terbiasa dengan barang yang selalu up to date, lebih mementingkan liburan untuk memenuhi keinginan swafoto di tempat yang indah dibandingkan memenuhi kebutuhan hidup utamanya, serta seringkali menghabiskan waktu di kafe mahal atau bahkan membeli baju rancangan desainer.

Beberapa penelitian sebelumnya melihat tingkat literasi keuangan pada anak muda (Das, 2017; de Bassa Scheresberg, 2013; Friedline \& West, 2016; Mottola, 2014). Hasil penelitian-penelitian tersebut menunjukkan bahwa tingkat literasi keuangan dewasa muda masih sangat rendah meskipun mereka tergolong financially active, terbukti dari kepemilikan kartu kredit. Tingkat literasi keuangan akan meningkat seiring dengan meningkatnya kepercayaan.

\section{Kepercayaan}

Menurut Kotler (2009: 176), kepercayaan diartikan sebagai sebuah pemikiran deskriptif yang dimiliki seseorang tentang suatu hal. Para calon konsumen memiliki kecenderungan untuk mengembangkan serangkaian keyakinan mengenai ciri-ciri dari suatu produk akan digunakannya dan selanjutnya, melewati keyakinan ini, diharapkan 
dapat membentuk sikap para calon konsumen terhadap produk tersebut. Lamb dalam Kotler (2009) mengungkapkan bahwa kepercayaan adalah sebuah pola yang diorganisir melalui pengetahuan yang kemudian dipegang oleh seorang individu sebagai sebuah kebenaran dalam menjalankan kehidupannya.

Sebagian besar masyarakat, khususnya bangsa Jepang, kepercayaan dianggap hal terpenting di dalam melakukan sebuah kegiatan transaksi. Kepercayaan dikatakan sebagai sebuah keyakinan bahwa seseorang akan dapat menemukan apa saja yang diinginkannya pada mitra pertukrannnya. Kepercayaan itu sendiri melibatkan kesediaan seseorang untuk bertingkah laku tertentu karena memiliki kayakinan tersendiri bahwa mitra atau rekannya akan dapat memberikan apa yang diharapkan dan harapan yang umumnya dimiliki oleh seseorang adalah kata, janji, ataupun pernyataan dari orang lain dapat dipercaya (Barnes, 2003).

Menurut Barnes (2003, 149): 'Terdapat beberapa elemen penting yang terkait dengan kepercayaan, yaitu:

1. Kepercayaan merupakan perkembangan dari pengalaman dan tindakan seseorang di masa yang lalu.

2. Watak atau sifat yang diharapkan dari mitra atau rekannya, seperti terpercaya dan dapat diandalkan.

3. Kepercayaan melibatkan seseorang dalam ketersediaannya untuk menempatkan dirinya dalam risiko tertentu.

4. Kepercayaan melibatkan perasaan aman dan yakin seseorang pada diri mitra atau rekannya".

Kepercayaan secara jelas akan sangat bermanfaat dan penting di dalam membangun sebuah relationship, meskipun untuk menjadi pihak yang dapat dipercaya tidaklah pekerjaan yang mudah. Untuk mencapai kepercayaan tersebut diperlukan usaha bersama antara konsumen dengan mitra atau rekannya.

Morgan dan Hunt (1994) menyatakan bahwa relationship commitment dan relationship trust adalah kunci bagi kesuksesan pemasaran relasional. Komitmen dan kepercayaan secara langsung membawa perilaku kerjasama yang mendorong kesuksesan pemasaran relasional. Keduanya mendorong pemasar untuk:

1. Bekerjasama dengan mitra atau rekan pertukaran dalam menjaga relationship.

2. Cenderung menolak benefit jangka pendek untuk dapat memperoleh benefit jangka panjang.

3. Memandang sebuah kegiatan yang memiliki potensi atas risiko yang tinggi dengan cara bijaksana dan berkeyakinan bahwa mitra atau rekan mereka tidak akan bertindak secara oportunis.

Kepercayaan bahkan dianggap sebagai faktor paling krusial dalam relasi, sekaligus berpengaruh terhadap komitmen. Apabila kepercayaan tidak ada, maka komitmen pun tidak akan ada (Tjiptono 2010: 415). Hal ini dapat diperkuat pula oleh beberapa hasil-hasil penelitian terdahulu yang menunjukkan pengaruh kepercayaan terhadap preferensi menabung pada perbankan syariah adalah berpengaruh signifikan (Lestari, 2015; Maski, 2010).

Penelitian mengenai kepercayan generasi milenial terhadap lembaga keuangan syariah ini sangat perlu untuk dilakukan mengingat masih terbatasnya hasil-hasil penelitian mengenai generasi milenial, khususnya dalam hal kepercayaan. Padahal generasi milenial ini merupakan generasi terbanyak dalam populasi dunia saat ini yang secara tak langsung menunjukkan bahwa para generasi ini merupakan pasar potensial sehingga pemasar harus mengetahui percaya tidaknya generasi tersebut atas lembaga atau produk yang dihasilkan. Jika suatu kelompok masyarakat sudah percaya, kedepannya diharapakan mampu 
membentuk minat beli produk yang dihasilkan oleh sebuah perusahaan yang terpercaya tersebut.

\section{Kerangka Berpikir Penelitian}

Berdasarkan tujuan penelitian dan tinjauan literatur, maka dapat digambarkan kerangka berpikir penelitian sebagai berikut:

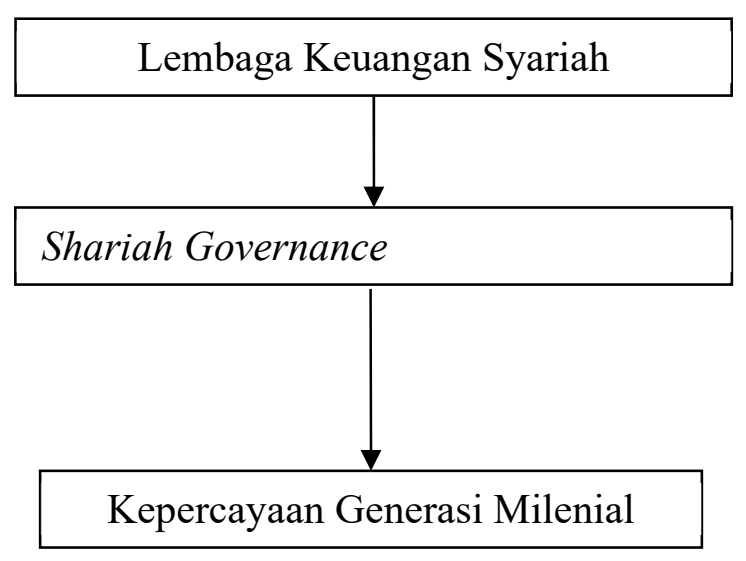

Gambar 2. Kerangka Berpikir Penelitian

Kerangka pemikiran yang ada pada Gambar 2 menunjukkan arah penelitian yang akan dilakukan saat ini. Mengingat perkembangan lembaga keuangan syariah saat ini yang cenderung lambat, maka peneliti ingin melihat bagaimana bagaimana kepercayaan para generasi milenial terhadap lembaga keuangan syariah. Dipilihnya generasi milenial karena beberapa penelitian sebelumnya telah mencoba melihat kelompok demografi tertentu, tetapi masih belum ada yang megaitkan generasi milenial dengan kepercayaan.

\section{METODE PENELITIAN}

\section{Metode Pengumpulan Data}

Populasi dalam penelitian ini adalah generasi milenial Nusa Tenggara Barat yang berusia minimal 20 tahun - 40 tahun sesuai rentang generasi milenial dan mengetahui adanya lembaga keuangan syariah. Oleh karena penduduk Nusa Tenggara Barat yang memiliki kriteria tersebut tidak diketahui jumlahnya secara pasti. maka metode pengumpulan data yang digunakan untk penelitian ini adalah metode sample survey. Metode sample survey merupakan metode pengumpulan data yang dilakukan hanya terhadap sebagian dari anggota populasi (Sugiyono, 2007).

\section{Sampel Penelitian}

Jumlah sampel dalam penelitian ini adalah sebanyak 50 orang responden. Jumlah ini didasari oleh pendapat Roscoe (1975, dalam Sekaran, 2006) yang menyatakan bahawa ukuran sampel lebih dari 30 dan kurang dari 500 adalah tepat untuk kebanyakan penelitian. Untuk memperoleh 50 orang responden ini digunakan teknik non-probability sampling dengan accidental sampling. 


\section{Jenis dan Sumber Data}

Jenis data dalam penelitian ini yang kualitatif dan kuantitatif. Untuk data kualitatif ada beberapa data yang akan dikuantitaifkan (seperti: jawaban responden) agar memudahkan peneliti di dalam menginterpretasikan hasil. Seumber data dalam penelitian ini data primer.

\section{Variabel Penelitian}

Adapun variabel pada penelitian ini adalah kepercayaan generasi milenial yang ada di Provinsi Nusa Tenggara Barat terhadap lembaga keuangan Syariah. Untuk melihat kepercayaan generasi milenial ini, responden akan diberikan seperangkat pernyataan tertutup. Seperangkat pernyataan tersebut mengacu pada Peraturan Bank Indonesia Nomor 11/33/PBI/2009 prinsip GCG lembaga keuangan syariah terdiri dari keterbukaan (transparancy), akuntabilitas (accountability), pertanggungjawaban (responsibility), independensi (independency), dan kewajaran (fairness). Selain kelima prinsip GCG tersebut, ada juga shariah compliance terkait dengan kepatuhan dari lembaga keungan syariah dalam menerapkan prinsip-prinsip syariah. Dengan kata lain kuesionair yang digunakan dalam penelitian ini sudah baku, sehingga tidak lagi dilakukan uji reliabilitas dan uji validitasi instrumen penelitian. Penyebaran kuesionair akan dilakukan secara online (online survey) agar dapat terjangkau ke berbagai wilayah di Nusa Tenggara Barat.Untuk melihat kepercayaan generasi milenial akan digunakan skala pengukuran dengan menggunakan skala Likert. Likert merupakan suatu skala yang paling banyak digunakan dalam riset berupa survey untuk mengukur sikap, perilaku, perndapat, dan persepsi seseorang terhadap fenomena sosial (Atmojo, 2012)..

\section{Prosedur Analisis Data}

Penelitian ini dianalisis dengan dengan menggunakan statistik deskriptif (descriptive statistics) yang juga disebut statistik deduktif (deductive statistics). Statistik deskriptif merupakan analisis yang paling mendasar untuk menggambarkan keadaan data secara umum. Analisis statistik deskriptif ini dapat berupa tabel frekuensi, eksplorasi data, tabulasi silang dan analisis rasio. Dalam penelitian ini data-data akan disajikan dalam bentuk tabel frekuensi dan indeksi kepercayaan generasi milenial. Tabel persepsi akan disusun berdasarkan indeks persepsi, seperti berikut.

Tabel 1.

Indeks Kepercayaan Generasi Milenial

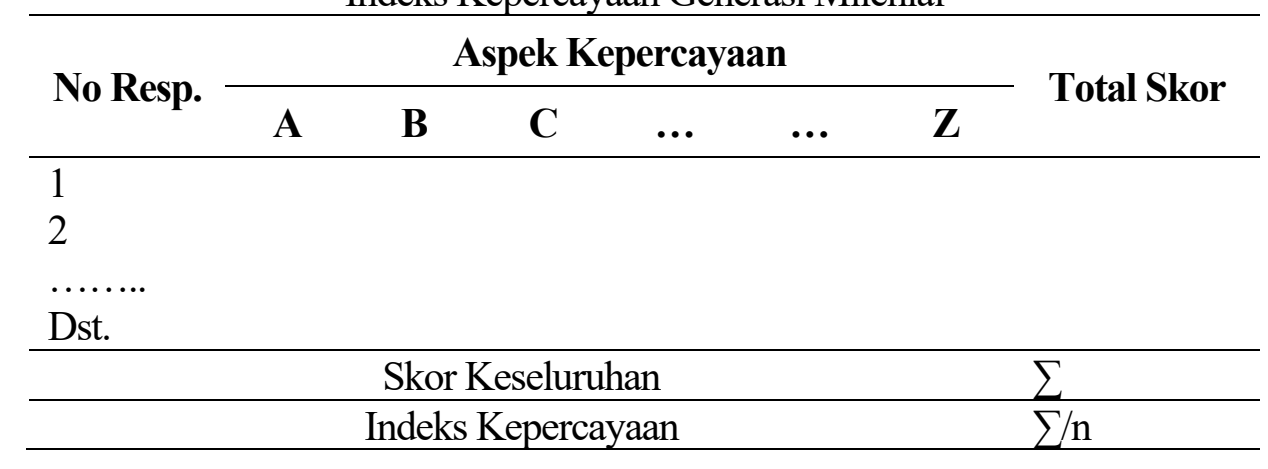

Setelah indeks kepercayaan generasi milenial diketahui, maka kriteria nilai kepercayaan tersebut dapat digolongkan sesuai tabel berikut: 
Tabel 2.

Kriteria Kepercayaan Generasi Milenial

\begin{tabular}{ccc}
\hline No. & Angka Indeks & Persepsi \\
\hline 1 & $1,00-1,80$ & Sangat Rendah \\
2 & $1,81 \leq 2,60$ & Rendah \\
3 & $2,61 \leq 3,40$ & Netral \\
4 & $3,41 \leq 4,20$ & Tinggi \\
5 & $4,21 \leq 5,00$ & Sangat Tinggi \\
\hline
\end{tabular}

\section{HASIL DAN PEMBAHASAN}

Deskripsi data indikator menggambarkan tanggapan generasi milenial selaku responden penelitian mengenai kepercayaan generasi milenial terhadap lembaga keuangan syariah. Data hasil penelitian kemudian dikategorikan sesuai dengan Tabel 3.3 mengenai kriteria kepercayaan generasi milenial.

Tabel 3.

Kriteria Kepercayaan Generasi Milenial Tahun 2020

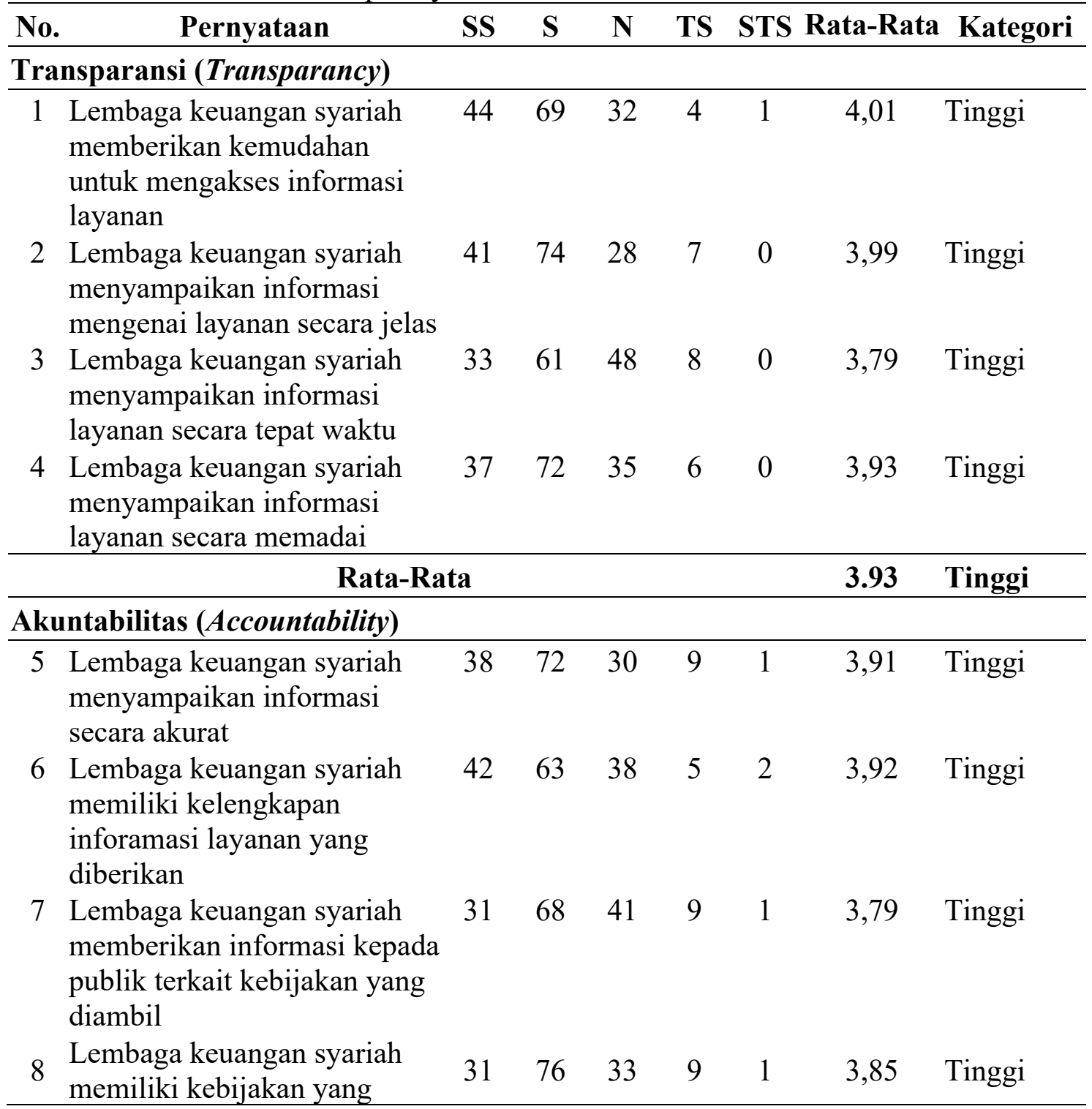




\begin{tabular}{|c|c|c|c|c|c|c|c|c|}
\hline No. & Pernyataan & SS & $\mathbf{S}$ & $\mathbf{N}$ & TS & STS & Rata-Rata & Kategori \\
\hline 9 & $\begin{array}{l}\text { konsisten dengan ketentuan } \\
\text { yang berlaku } \\
\text { Lembaga keuangan syariah } \\
\text { memiliki kebijakan yang } \\
\text { sesuai dengan ketentuan yang } \\
\text { berlaku }\end{array}$ & 38 & 74 & 32 & 6 & 0 & 3,96 & Tinggi \\
\hline \multicolumn{3}{|c|}{ Rata-Rata } & & & & & 3,88 & Tinggi \\
\hline \multicolumn{9}{|c|}{ Pertanggungjawaban (Responsibility) } \\
\hline 10 & $\begin{array}{l}\text { Lembaga keuangan syariah } \\
\text { taat pada peraturan } \\
\text { perundang-undangan yang } \\
\text { berlaku }\end{array}$ & 66 & 53 & 28 & 2 & 1 & 4,21 & $\begin{array}{l}\text { Sangat } \\
\text { Tinggi }\end{array}$ \\
\hline 11 & $\begin{array}{l}\text { Lembaga keuangan syariah } \\
\text { peduli kepada masyarakat } \\
\text { sekitar }\end{array}$ & 37 & 60 & 45 & 7 & 1 & 3,83 & Tinggi \\
\hline 12 & $\begin{array}{l}\text { Lembaga keuangan syariah } \\
\text { bertanggung jawab atas } \\
\text { layanan yang diberikan }\end{array}$ & 46 & 73 & 27 & 3 & 1 & 4,07 & Tinggi \\
\hline \multicolumn{3}{|c|}{ Rata-Rata } & & & & & 3,88 & Tinggi \\
\hline \multicolumn{9}{|c|}{ Independensi (Independency) } \\
\hline 13 & $\begin{array}{l}\text { Lembaga keuangan syariah } \\
\text { pasti mampu melindungi } \\
\text { semua kepentingan nasabah }\end{array}$ & 45 & 61 & 39 & 5 & 0 & 3,97 & Tinggi \\
\hline 14 & $\begin{array}{l}\text { Lembaga keuangan syariah } \\
\text { selalu bersikap objektif dalam } \\
\text { pengambilan keputusan }\end{array}$ & 42 & 63 & 41 & 3 & 1 & 3,95 & Tinggi \\
\hline \multicolumn{3}{|c|}{ Rata-rata } & & & & & 3,96 & Tinggi \\
\hline \multicolumn{9}{|c|}{ Keadilan (Fairness) } \\
\hline 15 & $\begin{array}{l}\text { Lembaga keuangan syariah } \\
\text { memperlakukan semua pihak } \\
\text { secara adil }\end{array}$ & 42 & 61 & 40 & 7 & 0 & 3,92 & Tinggi \\
\hline 16 & $\begin{array}{l}\text { Lembaga keuangan syariah } \\
\text { memberikan kesempatan } \\
\text { kepada masyarakat untuk } \\
\text { memberikan masukan (saran) }\end{array}$ & 42 & 68 & 36 & 4 & 0 & 3,99 & Tinggi \\
\hline 17 & $\begin{array}{l}\text { Lembaga keuangan syariah } \\
\text { memberikan kesempatan } \\
\text { kepada masyarakat untuk } \\
\text { memberikan kritikan }\end{array}$ & 39 & 70 & 35 & 6 & 0 & 3,95 & Tinggi \\
\hline 18 & $\begin{array}{l}\text { Lembaga keuangan syariah } \\
\text { mendindaklanjuti setiap } \\
\text { kritikan }\end{array}$ & 26 & 40 & 70 & 13 & 1 & 3,51 & Tinggi \\
\hline
\end{tabular}




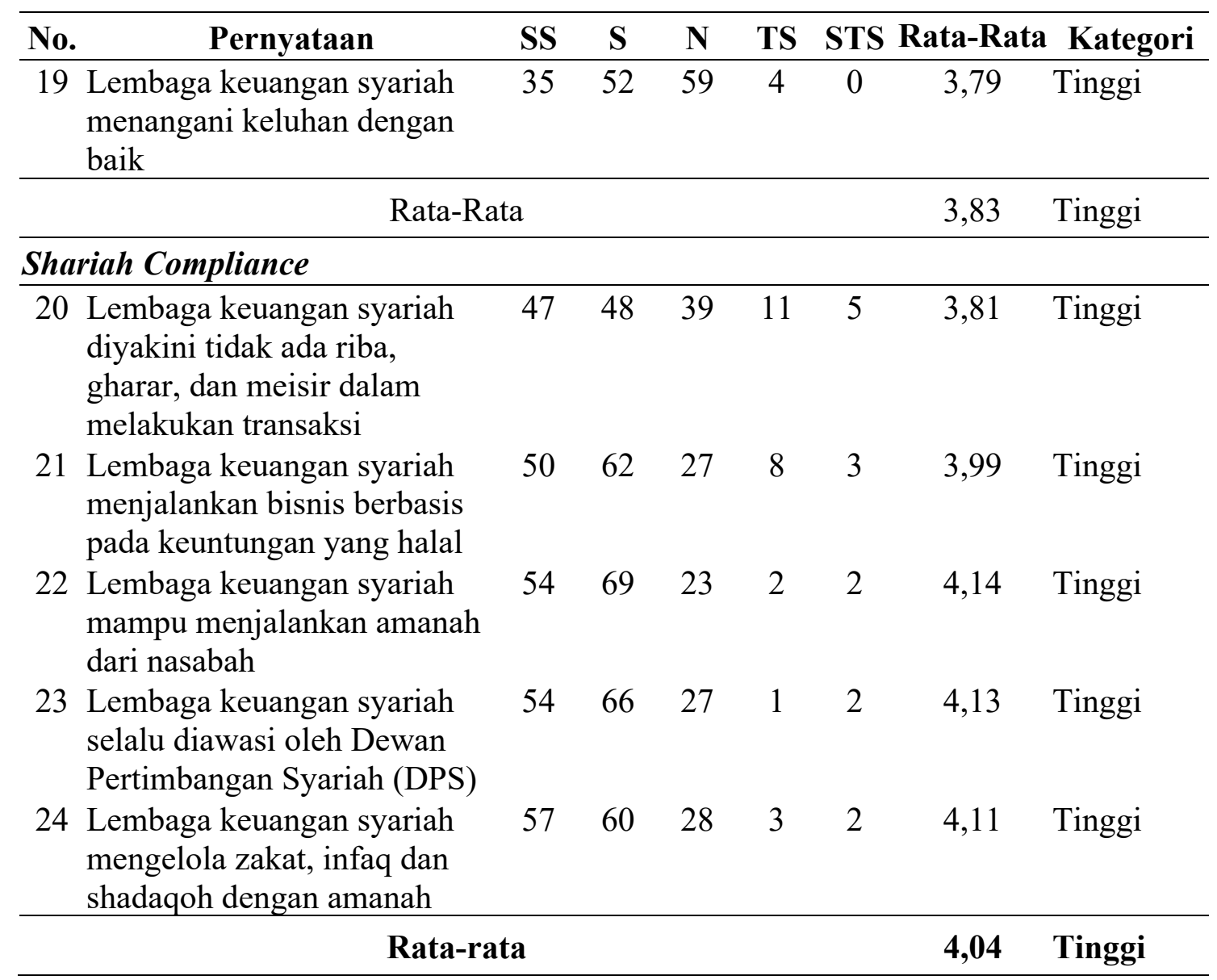

Sumber: Data Primer, 2020

Berdasarkan Tabel 3 mengenai kriteria kepercayaan generasi milenial terhadap lembaga keuangan syariah terlihat bahwa generasi milenial memiliki kepercayaan yang tinggi. Hal ini membuktikan bahwa para generasi milenial yang ada di Provinsi Nusa Tenggara Barat pada dasarnya sudah memiliki kepercayaan yang baik terhadap operasionalisasi lembaga keuangan syariah. Bahkan untuk indikator pertanggungjawaban (responsibility) terdapat satu (1) item pernyataan yang memiliki kriteria jawaban sangat tinggi terkait dengan percayanya generasi milenial bahwa lembaga keuangan syariah taat pada peraturan perundang-undangan yang berlaku.

Penelitian ini bertujuan untuk melihat kepercayaan generasi milenial yang ada di Nusa Tenggara Barat (NTB) terhadap lembaga keuangan syariah. Dari hasil penelitian diketahui bahwa para generasi milenial NTB memiliki kepercayaan yang tinggi terhadap lembaga keuangan syariah. Hal ini memperkuat hasil penelitian Septiani, dkk. (2018) yang menyatakan bahwa persepsi masyarakat umum Kota Mataram NTB adalah baik.

Diantara item pernyataan yang membentuk kepercayaan generasi milenial, terdapat satu item pernyataan dalam indikator pertanggungjawaban (responsibility) yang memiliki nilai dengan kategori sangat tinggi. Pernyataan yang memiliki nilai sangat tinggi dari para generasi milenialtersbut berkaitan dengan ketaatan lembaga keuangan syariah terhadapa peraturan perundang-undangan yang berlaku. Peraturan yang dimaksud dalam hal ini adalah Peraturan Ketua Badan Pengawas Pasar Modal dan Lembaga Keuangan Nomor PER-06/BL/2012 tentang perubahan Peraturan Ketua Badan Pengawas Pasar Modal dan Lembaga Keuangan Nomor PER-03/BL/2007 tentang Kegitan Perusahaan Pembiayaan Berdasarkan Prinsip Syariah di mana isinya antara lain berkaitan dengan 
akad-akad yang digunakan dalam kegiatan perusahaan pembiayaan dengan prinsip syariah dan dalam melaksanakan kegiatan operasionalnya, setiap lembaga keuangan syariah ini diawasi oleh Dewan Pengawas Syariah yang diangkat oleh DNS-MUI. Dengan adanya Dewan Pengawas Syariah ini, para generasi milenial merasa semakin percaya bahwa lembga keuangan syariah ini benar-benar telah menerapkan prinsip syariah dalam seluruh aspek kegiatan perusahaannya baik yang bersifat operasional maupun nonoperasional.

\section{KESIMPULAN DAN SARAN}

Berdasarkan hasil penelitian yang telah dilakukan Berdasarkan hasil penelitian dan pembahasan yang telah dilakukan, maka dapat ditarik kesimpulan bahwa generasi milenial yang ada di Nusa Tenggara Barat memiliki kepercayaan yang tinggi terhadap lembaga keuangan syariah. Masayarakat percaya terhadap transparansi $(3,93)$, akuntabilitas $(3,88)$, pertanggungjawaban $(4,07)$, independensi $(3,96)$, keadilan $(3,83)$, dan shariah compliance $(4,04)$ yang dilakukan oleh lembaga keuangan syariah. Mengingat kepercayaan generasi milenial yang tinggi, lembaga keuangan syariah perlu memberikan edukasi yang lebih mendalam lagi mengenai produk keuangan syariah sehingga para generasi milenial tidak hanya sebatas percaya tetapi juga bersedia untuk memutuskan berinvestasi produk keuangan syariah.

Penelitian yang dilakukan saat ini masih bersifat deskriptif sehingga disarankan untuk peneliti selanjutnya dapat lebih mendalam dengan melihat seberapa besar pengaruh kepercayaan para generasi milenial Nusa Tenggara Barat terhadap minat berinvestasi produk syariah. Penelitian ini hanya melihat kepercayaan generasi mileneial yang di Nusa Tenggara Barat, sehingga kedepannya dapat menambahkan variabel ketertarikan dan/atau keputusan investasi produk sayriah. Seain itu, jumlah sampel yang digunakan dalampenelitian ini masih terbatas dari segi kuantitas, kedepannya perlu ditambah jumlahnya atau menambah proporsi sampel dari masing-masing wilayah agar hasil penelitian benar-benar dapat menggambarkan kondisi populasi yang sebenarnya.

\section{REFERENSI}

Atmojo, A. R. D. 2012. Persepsi Pengunjung Terhadap Kualitas Pelayanan Pada Museum Mulawarman Tenggarong. Jurnal Penelitian Pariwisata Politeknik Negeri Samarinda. Diakses tanggal 22 Januari 2018. Dari http://www.karyailmiah.polnes.ac.id.

Agustianto. 2001. Konsep dan Sistem Perbankan Syariah. Medan: FKEBI - SU.

Bank Indonesia. 2009. Peraturan Bank Indonesia Nomor 11/33/PBI/2009. Jakarta: Bank Indonesia.

Barnes, James G. 2003. Secret of Customer Relationship Management. New York: McGraw-Hill.

Billah, Zahida I'tisoma. 2019. Pengenalan Investasi Akhirat Melalui Gerakan Nabung Wakaf Untuk Generasi Milenial. Prosiding Annual Conference for Muslim Scholar UIN Sunan Ampel Surabaya, hal. 129 - 136. 
Cordington, Graeme and Sue Grant-Marshal. Update Edition 2011 (originally: 2004): Understanding Different Generations: Own Your Past, Know Your Generation, Choose Your Future ISBN: 978-0143528418 ASIN: B009TRAAAA.

Cooper, Rich. 2012. The Milenial Generation: Research Review. Washington D.C.: National Chamber Foundation (U.S Chamber of Commerce).

Das, S. C. (2017). Financial Literacy among Indian Millennial Generation and their Reflections on Financial Behaviour and Attitude : .... (September).

de Bassa Scheresberg, C. (2013). Financial literacy and financial behavior among young adults: Evidence and implications. Numeracy, 6(2), 1-21.

DSN MUI. 2003. Himpunan Fatwa Dewan Syariah Nasional Edisi 2. Jakarta: DSN-MUI dan Bank Indonesia.

Friedline, T., \& West, S. (2016). Financial education is not enough: Millennials may need financial capability to demonstrate healthier financial behaviors. Journal of Family and Economic Issues, 37(4), 649-671.

Junusi, Rahman El. Implementasi Syariah Governance Serta Implikasinya Terhadapa Reputasi dan Kepercayaan Bank Syariah. Jurnal Al-Tahrir, Vol.12, No.1, hal. 91 115.

Kotler, Philip dan Kevin Lane Keller. 2009. Manajemen Pemasarn Edisi 12 Jilid I, Terjemahan: Benyamin Molan. Jakarta: P.T. Indeks.

Larasati, Niken Febria. 2019. Analisis Perilaku Generasi Milenial Terhadap Niat Menjadi Nasabah Bank Syariah. Thesis Fakultas Ekonomi dan Bisnis UIN Syarif Hidayatullah Jakarta.

Lestari. 2015. Pengaruh Religiusitas, Produk Bank, Kepercayaan, Pengetahuan, dan Pelayanan terhadap Preferensi Menabung pada Perbankan Syariah (Studi Kasus Pada Mahasiswa Fakultas Ekonomi dan Bisnis Universitas Brawijaya Malang). Jurnal Ilmiah Mahasiswa FEB Vol 3 (No 1).

Maski, Ghozali. 2010. Analisis keputusan nasabah menabung: Pendekatan komponen dan model logistik studi pada bank syariah di Malang. Journal of Indonesian Applied Economics, 4(1).

Morgan, Robert M. and Shelby D. Hunt. 1994. The Commitment-Trust Theory of Relationship Marketing, Journal of Marketing, 58 (3): 20-38.

Mottola, G. R. 2014. The Financial Capability of Young Adults - A Generational View. FINRA Foundation Financial Capability Insights, March(March), 1-12. https://doi.org/10.13140/RG.2.1.3800.5281

Ningtyas, Mega Noerman. 2019. Literasi Keuangan Pada Generasi Milenial. Jurnal Ilmiah Bisnis dan Ekonomi Asia, Vol 13, No. 1. Hal. 20 - 27.

Otoritas Jasa Keuangan (OJK). 2018. Laporan Perkembangan Keuangan Syariah Tahun 2018. Jakarta: OJK.

Sekaran, Uma. 2006. Metode Penelitian Untuk Bisnis. Jakarta: Salemba Empat. 
Septiani, Emilia dkk. 2018. Analisis Persepsi Masyarakat Umum Terhadap Produk Investasi Syariah dan Keputusan Untuk Berinvestasi. Jurnal Distribusi: Jurnal Ilmu Manajemen dan Bisnis Vol.6 No.1; hal 55-68.

Simbolon, Permadi. 2019. Teori Generasi dan Pembentukan Karakter Anak. Artikel diakses melalui https://www.indonesiana.id/read/112536/teori-generasi-danpembentukan-karakter-anak pada 27 Januari 2020, Pukul 20.05 WITA.

Strauss, W. and Howe, N. 1991. Generasi: Sejarah Amerika Masa Depan, 1594 ke 2069. New York: William Morrow \& Co.

Sugiyono. 2007. Metode Penelitian Bisnis. Bandung: Alfabeta.

Tjiptono, Fandy. 2010. Strategi Pemasaran Edisi 2. Yogyakarta: Andi Offset.

Wardayati, Siti Maria. 2011. Implikasi Shariah Governance Terhadap Keputusan dan Kepercayaan Bank Syariah. Jurnal Walisongo, Vol.19, No.1; hal 1 - 24.

Yanuar, Surya Putra. 2016. Theoritical Review: Teori Perbedaan Generasi. Jurnal Among Makarti, Vol.19, No.18.

https://ntb.bps.go.id/linkTableDinamis/view/id/2019 (Diakses Pada 27 Januari 2020, Pukul 20.43 WITA).

160 | Analisis Kepercayaan Generasi Milenial Terhadap Lembaga Keuangan Syariah ... 